\title{
Effect of oviposition by Bactrocera dorsalis on the antioxidant activity of orange juice
}

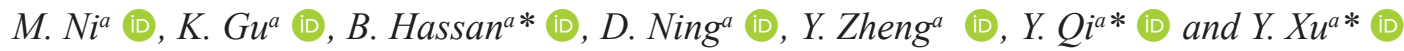

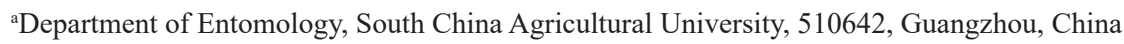 \\ *e-mail: sialuaf@gmail.com; qiyixiang@scau.edu.cn; xuyijuan@yahoo.com
}

Received: January 16, 2019 - Accepted: March 6, 2019 - Distributed: August 31, 2020

(With 2 figures)

\begin{abstract}
Among fruits and fruit products, oranges and orange juice are the most widely consumed worldwide. However, the effects of pest infestation of oranges on the quality of orange juice are not yet known. To evaluate the effect of the oriental fruit fly Bactrocera dorsalis on the antioxidant activity of orange juice, we measured changes in the vitamin $\mathrm{C}$ (Vc) concentration, total phenol content, and antioxidant activity of orange juice after the introduction of fruit fly eggs. Ten days after the eggs were introduced (larvae removed), the concentration of Vc in orange juice was $18.65 \mu \mathrm{g} / \mathrm{mL}$, which was $9.16 \mu \mathrm{g} / \mathrm{mL}$ lower than that measured in healthy orange juice. In addition, the total phenol content decreased by $46.519 \mathrm{mg}$ Gallic Acid Equivalents (GAE)/g to $9.748 \mathrm{mg} \mathrm{GAE} / \mathrm{g}$. Furthermore, the free-radical scavenging activity decreased from $22.297 \%$ to $5.393 \%$. Correlation analysis indicated significant correlations between Vc concentration, total phenol content, and antioxidant activity of orange juice after $B$. dorsalis infestation. The decrease in Vc concentration, total phenol content and free-radical scavenging activity indicated that $B$. dorsalis changed the quality of orange juice by affecting the antioxidant activity of the juice after the oranges were infested.
\end{abstract}

Keywords: fruit juice, pest infestation, Tephritid fruit fly, spectrophotometric method, DPPH.

\section{Efeito da oviposição de Bactrocera dorsalis na atividade antioxidante do suco de laranja}

\section{Resumo}

Entre frutas e produtos de frutas, as laranjas e suco de laranja são os mais consumidos em todo o mundo. No entanto, os efeitos da infestação de laranjas sobre a qualidade do suco de laranja ainda não são conhecidos. Para avaliar o efeito da mosca-das-frutas oriental, Bactrocera dorsalis, sobre a atividade antioxidante do suco de laranja, foram medidas as mudanças na concentração de vitamina $\mathrm{C}(\mathrm{Vc})$, no teor de fenol total e na atividade antioxidante do suco de laranja após a introdução de ovos da mosca-das-frutas oriental. Dez dias após a introdução dos ovos (larvas removidas), a concentração de Vc no suco de laranja foi de $18,65 \mu \mathrm{g} / \mathrm{mL}$, que foi 9,16 $\mu \mathrm{g} / \mathrm{mL}$ menor do que a medida em suco de laranja saudável. Além disso, o teor total de fenol diminuiu de 46,519 mg em equivalente de ácido gípico (GAE)/g para 9,748 mg de GAE/g. Ademais, a atividade de eliminação de radicais livres diminuiu de 22,297\% para 5,393\%. A análise de correlação indicou correlações significativas dentre a concentração de Vc, o conteúdo total de fenol e a atividade antioxidante do suco de laranja após a infestação por B. dorsalis. A diminuição na concentração de Vc, o conteúdo total de fenol e a atividade sequestradora de radicais livres indicaram que $B$. dorsalis alterou a qualidade do suco de laranja, afetando a atividade antioxidante do suco após a infestação das laranjas.

Palavras-chave: suco de fruta, infestação de pragas, mosca-das-frutas Tephritid, método espectrofotométrico, DPPH.

\section{Introduction}

A large number of studies showed that the intake of fruits and vegetables is helpful to reduce the incidence of cardiovascular, cerebrovascular diseases and tumors, which are closely related to the antioxidant function of active substances in fruits (Silalahi, 2002; Kaul et al., 2007; Pandey and Rizvi, 2009). Antioxidants have been confirmed to include phenolic metabolites, carotenoids and vitamin C (Vc) (Kaul et al., 2007). Fruits can be consumed fresh or used to make juice. Orange, Citrus sinensis (Osbeck), juice is the most popular and widely consumed fruit juice in the world, accounting for approximately two-thirds of the total global sales of fruit juice because of its bright color, high nutrition and pleasant aroma. Orange juice is rich in Vc concentration, which is an important source of this vitamin in daily diets (Fry et al., 1999). Therefore, orange juice has antioxidant and macula protection functions. 
In addition, orange juice plays an important role in the prevention of chronic and acute diseases owing to flavonoids, hesperidin, diosmin and other substances. Furthermore, orange juice is considered to have medicinal properties such as cancer prevention abilities and anti-inflammatory, anti-hypertensive, diuretic, painkilling and lipid-lowering activities (Emim et al., 1994; Galati et al., 1996; Naidu, 2003). However, all these properties can be threatened if diseases or pests including tephritid fruit flies attack the orange fruits.

The oriental fruit fly Bactrocera dorsalis (Hendel) is one of the major pests that infest fruit and reduce production in tropical and subtropical regions (Lin et al., 2004; Cheng et al., 2017). More than 200 types of fruits including citrus, mango, guava, annonaceous species, carambola and loquat infested by $B$. dorsalis are listed as quarantine fruit in China (Zhang et al., 2008). Bactrocera dorsalis females lay eggs between the peel and flesh of fruit. When the larvae hatch, they eat and damage the fruit and gradually penetrate into the flesh, causing the whole fruit to rot (Rattanapun et al., 2009; Xu et al., 2012). Although it is well recognized that feeding of insect pests often causes changes in the physical and chemical properties of the host plants (Kaul et al., 2007), deposition of eggs by insects can also change the primary and secondary metabolism of plants (Hilker and Meiners, 2011).

Plants respond to herbivores and pathogen through various mechanisms and produce a huge variety of secondary metabolites as defense chemicals such as phenolic compounds (Whitehead and Bowers, 2014). Besides the other plant parts, these chemicals also play a key role in fruit defence, and different individual compounds from fruits can be effective against different classes of insects and microbes (Whitehead and Bowers, 2013). Previous studies showed that inoculation of microbes to apple fruits changes its peroxidase and total phenolic compound compared to non-inoculated fruits (Mikani et al., 2011). Inoculation also altered the antioxidant activities in fresh cut melon; however, no significant effect on ascorbic acid (VC) was observed (Plaza et al., 2016). Phenolic compound are reason of taste and astringency (Ruiz-Cruz et al., 2017) and change in these compounds ultimately leading to change in fruit juice quality and chemical composition. There is still a lack of research on whether the antioxidant activity of orange fruit juice is affected by egg deposition of tephritid fruit flies. The question remains as to whether insect-infested fruit can be used to make fruit juice. In addition, the relationship between the degree of damage and the quality of the fruit juice is unclear.

This study determined the concentrations of $\mathrm{Vc}$ (vitamin C), phenolic compounds, and the antioxidant activity in fruit juice made with oranges that have been infested by $B$. dorsalis at different time after the introduction of eggs into oranges and then further evaluated the effect of $B$. dorsalis damage on fruit juice quality.

\section{Material and Methods}

\subsection{Reagents}

The main chemical reagents used in this experiment were sulfuric acid (AR 98\%, Tianjin Fuchen Chemical Reagent Factory, Tianjin, China); oxalic acid (AR 99\%, Tianjin Damao Chemical Reagent Factory, Tianjin, China); thiourea 2\% (AR, Tianjin Fuchen Chemical Reagent Factory, Tianjin, China); 2,4-dinitrophenylhydrazine (AR 99\%, Shanghai Meirel Chemical Technology Co., Ltd. Shanghai, China); anhydrous sodium carbonate (AR, Tianjin Baishi Chemical Co., Ltd., Tianjin, China); Folin-phenol reagent (2 mol/L, Beijing Dingguo Changsheng Biotechnology Co., Ltd., Beijing, China); 1,1-diphenyl-2-trinitrophenylhydrazine (AR 97\%, Tixiai (Shanghai) Chemical Industry Development Co., Ltd., Shanghai, China); and anhydrous ethanol (AR, Tianjin Yongda Chemical Reagent Co., Ltd., Tianjin, China).

\subsection{Flies and egg inoculation}

Bactrocera dorsalis reared in the Department of Entomology, South China Agricultural University was used in the current experiment. Adult $B$. dorsalis were fed an artificial diet (sugar and yeast powder (torula yeast; Cyberlindnera jadinii), 1:3 w/w) and water. Fresh oranges, C. sinensis of similar size and maturity were purchased from three local supermarkets (replicates). Bactrocera dorsalis females usually varies in egg number at each oviposition and therefore it's difficult to estimate or control the number of egg per fruit based on the number of oviposition scars, or use varying densities. For the precise control of equal egg density across replicates, oranges were infested artificially by egg inoculation. The exocarp (approximately $1 \mathrm{~cm}^{2}$ for each cut) of each orange was cut with a sterilized knife, and six recently collected eggs were introduced into the interface between the sarcocarp and the exocarp with a brush at each cut. Totally 30 eggs were introduced to five cuts of each orange. Then, the cut exocarp was returned to its original position without sealing, and the oranges were separately placed into a plastic box and were maintained at $25{ }^{\circ} \mathrm{C}$. Three and ten days after egg inoculation, six oranges were removed for subsequent experiments.

Preliminary experiments showed that the concentration of Vc, total phenol content and free-radical scavenging activity measured in oranges with the $1-\mathrm{cm}^{2}$ exocarp incision did not change significantly within 10 days. Consequently, three oranges were randomly selected as the control; their outer rind was cut, and then the oranges were juiced and discarded.

To determine the effect of presence of absence of larvae on juice quality, after egg inoculation, three of the oranges were directly peeled and juiced without removing the insects, whereas the insects were removed from other three oranges and juiced. Most of the eggs did not hatch or some hatched within three days after the inoculation in the fruit, leading to no significant difference in the indicators between the insect removal and insect retention groups; therefore, we did not make a distinction between the treatments on the third day. 


\subsection{Effect of $B$. dorsalis infestation on the $V c$ concentration of orange juice}

Two milliliters of orange juice and $2 \mathrm{~mL}$ of a $2 \%$ oxalic acid solution were placed in a small beaker and then mixed. Then, $1 \mathrm{~mL}$ of this mixture was taken in a volumetric flask (25-mL), diluted to $25 \mathrm{~mL}$ with $1 \%$ oxalic acid solution, and allowed to stand for $10 \mathrm{~min}$ before filtration. Subsequently, $1 \mathrm{~g}$ of activated carbon was added to the above filtrate, shaken for $1 \mathrm{~min}$ and filtered again. A $12.5-\mathrm{mL}$ thiourea solution $(2 \%)$ was added to $12.5 \mathrm{~mL}$ of the above filtrate and mixed in a $50-\mathrm{mL}$ colorimetric tube. Then, the samples were preserved in a water bath at $37.2^{\circ} \mathrm{C}$ for $3 \mathrm{~h}$, placed in ice water for $1 \mathrm{~min}$ and after cooling at room temperature, $1 \mathrm{~mL}$ of a $2 \%$ 2, 4-dinitrophenylhydrazine solution was added, and the solution was incubated for 10-15 minutes at room temperature. The solution was then placed in ice water, and $5 \mathrm{~mL}$ of an $85 \%$ sulfuric acid solution was added drop wise, shaking when dropping to prevent carbonization. The solution was allowed to stand at room temperature for 30-35 minutes and the absorbance was measured with a Nano 300 micro spectrophotometer (Yuanping Hao Biotechnology Co., Ltd., Beijing, China) at a wavelength of $500 \mathrm{~nm}$. We calculated the Vc concentration of orange juice using the following standard curve Equation 1:

$\mathrm{Y}=0.0234 \mathrm{X}+0.0679$

where $\mathrm{Y}$ is absorbance at $500 \mathrm{~nm}$, and $\mathrm{X}$ is the concentration of $\mathrm{Vc}$.

\subsection{Effect of B. dorsalis infestation on the total phenol content in orange juice}

Orange juice $(0.1 \mathrm{~mL})$ and distilled water $(6 \mathrm{~mL})$ were placed in a $10-\mathrm{mL}$ volumetric flask, and $0.5 \mathrm{~mL}$ of Folin-phenol reagent was added and mixed well. One minute later, $1.5 \mathrm{~mL}$ of a sodium carbonate solution (20\%) was added, and the volume was made up to $10 \mathrm{~mL}$ using distilled water. The solution was allowed to stand in a darkroom at $25^{\circ} \mathrm{C}$ for 2 hours, after which the absorbance was measured at $760 \mathrm{~nm}$ using a Nano 300 micro spectrophotometer (Yuanping Hao Biotechnology Co., Ltd. Beijing, China). The total phenol content was determined using gallic acid as a standard, and expressed as mg Gallic Acid Equivalents (GAE)/100g of dry matter (DM) and the standard curve as follows was used (Equation 2):

$\mathrm{Y}=0.009 \mathrm{X}+0.0346$

where $\mathrm{Y}$ is absorbance at $760 \mathrm{~nm}$; and $\mathrm{X}$ is total phenol content.

\subsection{Effects of $B$. dorsalis infestation on the total antioxidant activity of orange juice}

The sample solution was prepared by placing $3 \mathrm{~mL}$ of orange juice in a $100-\mathrm{mL}$ volumetric flask, and $95 \%$ ethanol was added to obtain a $100-\mathrm{mL}$ sample solution. A 1,1-diphenyl2-trinitrophenylhydrazine (DPPH) solution was prepared by taking $0.128 \mathrm{~g}$ of DPPH in a $500-\mathrm{mL}$ volumetric flask and dissolving it with $95 \%$ ethanol to obtain a $257.7 \mathrm{mg} \cdot 1^{-1}$ DPPH stock solution $\left(6.5 \times 10^{-4} \mathrm{~mol} \cdot \mathrm{l}^{-1}\right)$; the solution was shaken adequately and was stored in a refrigerator until use. Then, $4 \mathrm{~mL}$ of the $257.7 \mathrm{mg} \cdot 1^{-1} \mathrm{DPPH}$ solution and $1.0 \mathrm{~mL}$ of $95 \%$ ethanol were added to a $10-\mathrm{mL}$ colorimetric tube. After shaking and stabilizing the reaction (reaction time $40 \mathrm{~min})$, the absorbance $\left(\mathrm{A}_{0}\right)$ was measured at $518.4 \mathrm{~nm}$ with $95 \%$ ethanol solution as a reference. Later, $4 \mathrm{~mL}$ of $95 \%$ ethanol and $1 \mathrm{~mL}$ of the sample solution were added to a $10-\mathrm{mL}$ colorimetric tube. After shaking and stabilizing the reaction (reaction time $40 \mathrm{~min}$ ), the absorbance $\left(\mathrm{A}_{\mathrm{r}}\right)$ was measured at $518.4 \mathrm{~nm}$ with $95 \%$ ethanol solution as a reference. Then, $4 \mathrm{~mL}$ of the $257.7 \mathrm{mg} \cdot 1^{-1} \mathrm{DPPH}$ solution and $1 \mathrm{~mL}$ of the sample solution were added to a $10-\mathrm{mL}$ colorimetric tube. After shaking and stabilizing the reaction (reaction time $40 \mathrm{~min}$ ), the absorbance (A) was measured at $518.4 \mathrm{~nm}$ with $95 \%$ ethanol solution as a reference. The free-radical scavenging activity (Y) was calculated according to the formula: $\mathrm{Y}(\%)=\left(1-\mathrm{A}_{0}-\mathrm{A}_{\mathrm{r}} / \mathrm{A}_{0}\right) \times 100$; Where $\mathrm{A}_{0}$ is the absorbance of the DPPH solution and $\mathrm{Ar}$ is the absorbance of the sample

\subsection{Statistical analysis}

Analyses were conducted using SPSS software v.13.0 (2011; IBM SPSS Statistics, Chicago, IL). One-way ANOVA was used to compare the differences in the Vc concentration, total phenol content and free-radical scavenging rate of orange juice among the different treatments, and Fisher's Least Significant Difference test (LSD) was used to make multiple comparisons. Correlation analysis was then carried out to determine significant correlations between different parameters.

\section{Results}

\subsection{Changes in the surface characteristics of oranges and the color of orange juice}

The degree of orange decay became increasingly serious in the inoculated fruit. The original smooth surface of the oranges did not change in the absence of egg inoculation. However, three days after egg inoculation, 1-mm black spots appeared, and after 10 days, the spots became larger (approximately $3 \mathrm{~cm}$ ). Based on visual observation, although there was no visual change in the color of orange juice of three days inoculated fruit compared to the control, a greener color significant difference in the color of the orange juice three days after egg inoculation compared with the control, a greener color was observed after 10 days. A foul redolence was observed in fruits after 3 and 10 days of introduction of the eggs (Figure 1).

\subsection{Effect of $B$. dorsalis infestation on the Vc contents of orange juice}

$\mathrm{Vc}$ concentration in orange juice differed among treatments $\left(F_{3,11}=32.053, P<0.001\right)$. Bactrocera dorsalis infested fruit had a significantly lower concentration than the control; this was more evident for 10 days after inoculation fruit (Table 1). Moreover, there was no significant difference in Vc contents between fruit with and without larvae removal (Table 1). 


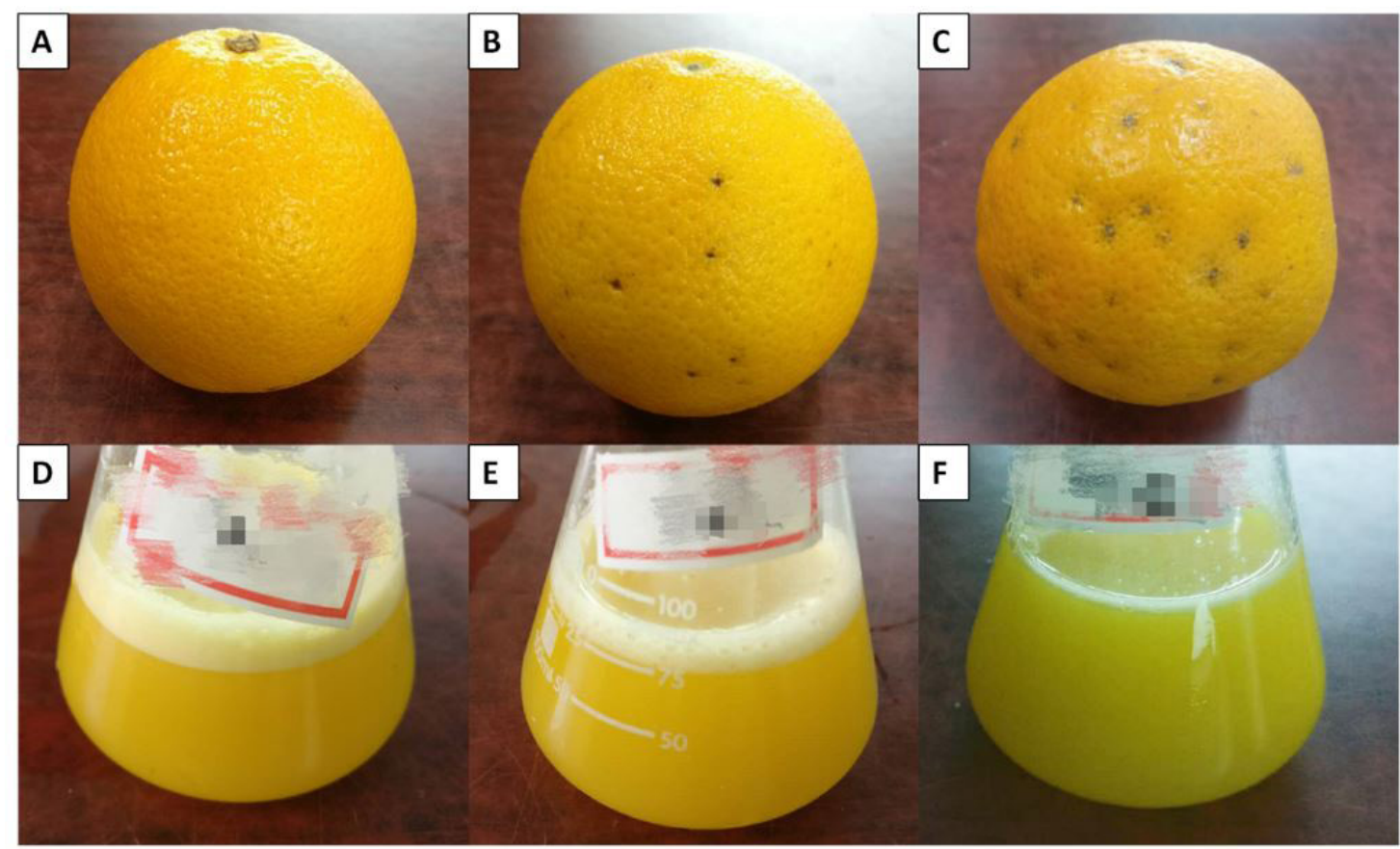

Figure 1. The orange fruit surface features and orange juice color without (A, D) and 3 days (B, E) and 10 days $(C, F)$ after egg inoculation.

Table 1. The Vc concentration, total phenol contents and total antioxidant activity of orange juice before and after egg inoculation of $B$. dorsalis.

\begin{tabular}{lcrr}
\hline \multicolumn{1}{c}{ Sample status } & $\begin{array}{c}\text { Mean }( \pm \mathbf{S E}) \mathbf{V c} \\
\text { concentration } \\
(\boldsymbol{\mu g} / \mathbf{m L})\end{array}$ & $\begin{array}{c}\text { Mean }( \pm \mathrm{SE}) \text { total } \\
\text { phenol content } \\
(\mathbf{m g} \mathbf{G A E} / \mathbf{g})\end{array}$ & $\begin{array}{c}\text { Mean }( \pm \mathrm{SE}) \\
\text { total antioxidant } \\
\text { activity }(\mathbf{Y} \%)\end{array}$ \\
\hline Control/Not inoculated & $27.810 \pm 0.242 \mathrm{a}$ & $56.267 \pm 0.832 \mathrm{a}$ & $27.690 \pm 0.449 \mathrm{a}$ \\
3 days after egg inoculation & $23.273 \pm 0.621 \mathrm{~b}$ & $40.137 \pm 1.132 \mathrm{~b}$ & $19.080 \pm 1.193 \mathrm{~b}$ \\
10 days after egg inoculation (larvae removed) & $18.650 \pm 2.262 \mathrm{c}$ & $9.748 \pm 1.003 \mathrm{~d}$ & $5.393 \pm 0.579 \mathrm{~d}$ \\
10 days after egg inoculation (larvae not removed) & $19.047 \pm 0.682 \mathrm{c}$ & $14.118 \pm 1.082 \mathrm{c}$ & $9.983 \pm 0.069 \mathrm{c}$ \\
\hline
\end{tabular}

$\mathrm{SE}=$ standard error; $\mathrm{Vc}=$ vitamin $\mathrm{C} ; \mathrm{Y}=$ antioxidant activity. Values followed by the same letter in each column indicate no significant difference based on ANOVA results $(P>0.05$, LSD test).

\subsection{Effect of B. dorsalis infestation on the total phenol content of orange juice}

The average total phenol content of healthy orange juice was $56.267 \mathrm{mg} \mathrm{GAE} / \mathrm{g}$, which was significantly higher than that in the other treatments $\left(F_{3,11}=1037.077, P<0.001\right)$. The total phenol content of orange juice decreased to $40.137 \mathrm{mg} \mathrm{GAE} / \mathrm{g} 3$ days after egg inoculation, and the decrease exceeded $40 \mathrm{mg} \mathrm{GAE} / \mathrm{g}$ after 10 days. In addition, the removal of larvae had a significant effect on the total phenol content of orange juice (Table 1).

\subsection{Effect of B. dorsalis infestation on the total antioxidant activity of orange juice}

The average free-radical scavenging activity of healthy orange juice was $27.69 \%$, indicating strong antioxidant activity. However, the free-radical scavenging rate was reduced considerably after the oranges were infested $\left(F_{3,11}=328.92, P<0.001\right)$. The free-radical scavenging rate measured in orange juice decreased significantly to $19.08 \%$ after 3 days and continued to decrease to less than $10 \%$ after 10 days. In addition, the removal of larvae had a significant effect on the free-radical scavenging rate measured in orange juice (Table 1).

\subsection{Correlation between Vc concentration, total phenol content and total antioxidant activity}

Correlation analysis showed that $\mathrm{Vc}$ concentration and total phenol content were positively correlated (Figure 2A). In addition, both $\mathrm{Vc}$ concentration and total phenol content were significantly positive correlated to total antioxidant activity (Figures 2B, C).

\section{Discussion}

The infestation of fruits by insects results in reduced yield and may also decrease the weight of a single fruit as well as affect the appearance characteristics such as fruit 

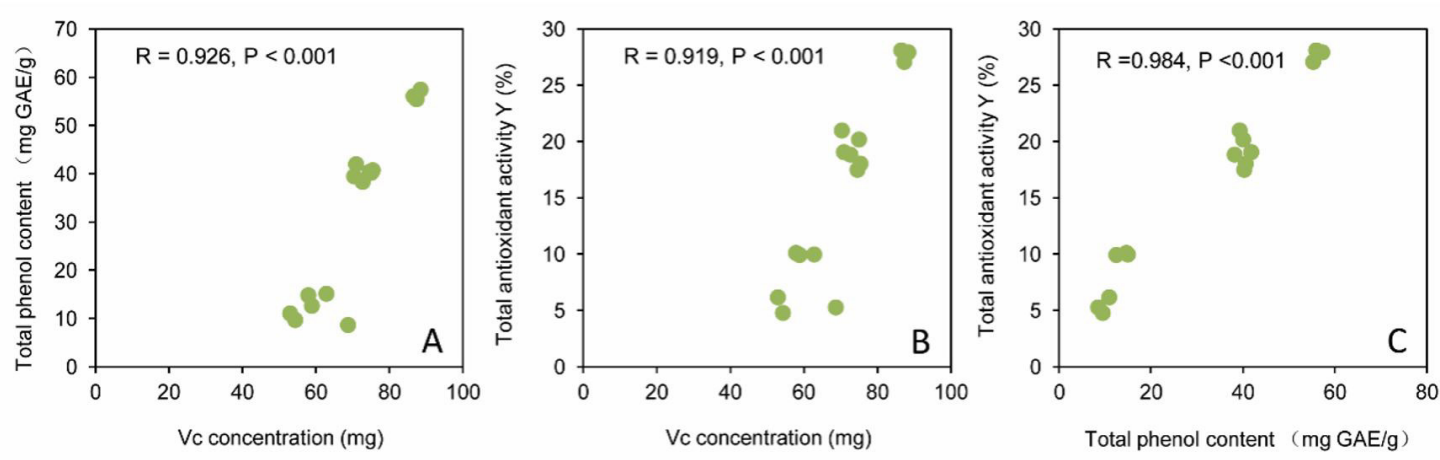

Figure 2. Relationship between $\mathrm{Vc}$ (vitamin $\mathrm{C}$ ) concentration and total phenol content (A), Vc concentration and total antioxidant activity (B), total phenol content and total antioxidant activity (C).

firmness and skin color (Fletcher, 1987). In addition to this, eggs of insects when laid on the plants or fruits can change the primary and secondary metabolism of plants or plant parts (Hilker and Meiners, 2011). As a result, pest infestation affect the content of soluble substances and the acidity and flavor characteristics of fruit (Birla et al., 2005). The results of the present study showed that the infestation of oranges by $B$. dorsalis affected both the appearance of the fruit and the color of the orange juice; a foul smell was also observed from infested fruits (Omoloye et al., 2016). Egg deposition by insects itself can change the odour of fruits (Bruce et al., 2010) or this may also be attributed to the rapid growth of green mold caused by Penicillium digitatum Saccis or Penicillium notatum, one of the most economically important postharvest diseases of citrus (Leelasuphakul et al., 2008; Omoloye et al., 2016). Infection was considered to occur through injuries made during piercing. Under natural conditions, fruits stung by fruit flies also decayed prematurely due to growth of several opportunistic fungi around the punctures made by fruit flies during oviposition and or on the ooze that comes out from fruits stung by fruit flies (Hill, 1983; Louis et al., 1996; Walsh et al., 2011). Newell and Haramoto (1968) also found that fungi and bacteria are closely involved in the complex interrelationship between the eggs of $B$. dorsalis, the oviposition activity of fruit fly and its parasitoid, Opius oophilus Fullaway. Oviposition punctures in citrus fruits made by Ceratitis capitata (Wiedemann) were also confirmed to be infected by colonies of Aspergillus sp. and Penicillium sp (Omoloye et al., 2016). Although changes in volatile odors were not measured in this study, unpleasant odors arose after the infestation of $B$. dorsalis and infection of opportunistic fungi; yet the differences in specific components need to be further determined.

Vitamin $\mathrm{C}(\mathrm{Vc})$ is one of the essential vitamins required by the human body; a strong natural antioxidant which plays a very important role in maintaining the normal physiological function of human body. Deficiency of Vc can lead to a variety of diseases (Padayatty et al., 2003). Oranges are one type of fruit that are rich in $\mathrm{Vc}$, and the $\mathrm{Vc}$ content in citrus fruits can be affected by water and soil fertility, light, temperature, storage and several other factors (Klimczak et al., 2007; Mo et al., 2018). Our study showed that the infestation of $B$. dorsalis also affects the content of $\mathrm{Vc}$ in the orange juice. These results suggests that the feeding holes formed by pests led to air circulation, which increased the oxygen content inside the fruit and accelerated the degradation of Vc (Green and Fry, 2005) or due to air present in the air chambers of eggs (Dias et al., 2018). This is in agreement with the results of Omoloye et al. (2016), who found that $C$. capitata infestation on sweet orange led to decrease in vitamin $\mathrm{C}$ contents progressively as the severity of attack increased. Furthermore, phenolic substances like flavonoids may also contribute to inhibit the photo oxidation of Vc (Del Caro et al., 2004; Wang et al., 2006), which may be verified by the positive relationship between $\mathrm{Vc}$ and total phenols in our study.

Oranges are rich in phenolic substances, mainly flavonoids and phenolic acids (Miller and Rice-Evans, 1997). These compounds have high biological activity and consequently, certain anti-oxidant, anti-inflammatory, anti-cancer and anti-bacterial activities in the human body (Naidu, 2003) as well as the ability to prevent cardiovascular diseases, diabetes and other ailments (Joshipura et al., 2001). The decrease in the total phenol content may be related to the enhanced activity of polyphenol oxidase and the effect of oxygen, which can enter the fruit pulp through the outlet hole produced by $B$. dorsalis larvae (Medjkouh et al., 2016). The phenolic substances decreased significantly after the infestation of $B$. dorsalis, and the content of these substances was less than $1 / 3$ that of the control 10 days after egg inoculation, indicating that the intense chemical reaction inside the fruit resulted in the metabolism of phenolic substances with the growth and development of the larvae. The decreased free-radical scavenging activity is probably due to the loss of polyphenols, flavonoids and o-diphenols (Mraicha et al., 2010). Other studies showed that the free-radical scavenging activity was positively correlated with the Vc concentration and total phenol content (Medjkouh et al., 2016). In this study, the phenol content and free-radical scavenging activity measured in orange juice decreased significantly after egg inoculation, which may indirectly indicate free-radical 
scavenging activity significantly decreased when $\mathrm{Vc}$ and phenol content decreased.

Given that orange juice is a popular beverage, the present study, which focused on the nutritional value of orange juice after pest infestation, has important practical significance. This study showed that the Vc concentration, phenolic content and antioxidant activity measured in orange juice significantly decreased after infestation by B. dorsalis, which affected the quality of the juice. These results also indicate that orange fruit is not suitable for juice production after pest infestation. Therefore, it is suggested that effective pest control measures be taken in areas with $B$. dorsalis fruit flies to reduce economic losses.

\section{Acknowledgements}

This study was supported by the National Key Research and Development Project (2016YC1201200).

\section{References}

BIRLA, S.L., WANG, S., TANG, J., FELLMAN, J.K., MATTINSON, D.S. and LURIE, S., 2005. Quality of oranges as influenced by potential radio frequency heat treatments against Mediterranean fruit flies. Postharvest Biology and Technology, vol. 38, no. 1, pp. 66-79. http://dx.doi.org/10.1016/j.postharvbio.2005.06.001.

BRUCE, T.J., MIDEGA, C.A., BIRKETT, M.A., PICKETT, J.A. and KHAN, Z.R., 2010. Is quality more important than quantity? Insect behavioural responses to changes in a volatile blend after stem borer oviposition on an African grass. Biology Letters, vol. 6, no. 3, pp. 314-317. http://dx.doi.org/10.1098/ rsbl.2009.0953. PMid:20031982.

CHENG, D.F., GUO, Z.J., RIEGLER, M., XI, Z.Y., LIANG, G.W. and XU, Y.J., 2017. Gut symbiont enhances insecticide resistance in a significant pest, the oriental fruit fly Bactrocera dorsalis (Hendel). Microbiome, vol. 5, pp. 13. http://dx.doi. org/10.1186/s40168-017-0236-z. PMid:28143582.

DEL CARO, A., PIGA, A., VACCA, V. and AGABBIO, M., 2004. Changes of flavonoids, vitamin $C$ and antioxidant capacity in minimally processed citrus segments and juices during storage. Food Chemistry, vol. 84, no. 1, pp. 99-105. http://dx.doi.org/10.1016/ S0308-8146(03)00180-8.

DIAS, N., NAVA, D., GARCIA, M., SILVA, F. and VALGAS, R., 2018. Oviposition of fruit flies (Diptera: Tephritidae) and its relation with the pericarp of citrus fruits. Brazilian Journal of Biology $=$ Revista Brasileira de Biologia, vol. 78, no. 3, pp. 443448. http://dx.doi.org/10.1590/1519-6984.167661. PMid:29091115.

EMIM, J.A.D.S., OLIVEIRA, A.B. and LAPA, A.J., 1994. Pharmacological evaluation of the anti-inflammatory activity of a citrus bioflavonoid, hesperidin, and the isoflavonoids, duartin and claussequinone, in rats and mice. The Journal of Pharmacy and Pharmacology, vol. 46, no. 2, pp. 118-122. http://dx.doi. org/10.1111/j.2042-7158.1994.tb03753.x. PMid:8021799.

FLETCHER, B.S., 1987. The biology of dacine fruit flies. Annual Review of Entomology, vol. 32, no. 1, pp. 115-144. http://dx.doi. org/10.1146/annurev.en.32.010187.000555.

FRY, J., MARTIN, G.G. and LEES, M., 1999. Authentication of orange juice Production and packaging of non-carbonated fruit juices and fruit beverages. Boston: Springer.
GAlATi, E.M., Trovato, A., KIRJAVAINEN, S., FORESTIERI, A.M., ROSSITTO, A. and MONFORTE, M.T., 1996. Biological effects of hesperidin, a Citrus flavonoid.(Note III): antihypertensive and diuretic activity in rat. Il Farmaco, vol. 51, no. 3, pp. 219-221. PMid:8688145.

GREEN, M.A. and FRY, S.C., 2005. Vitamin C degradation in plant cells via enzymatic hydrolysis of 4-O-oxalyl-L-threonate. Nature, vol. 433, no. 7021, pp. 83-87. http://dx.doi.org/10.1038/ nature03172. PMid: 15608627.

HILKER, M. and MEINERS, T., 2011. Plants and insect eggs: how do they affect each other? Phytochemistry, vol. 72, no. 13, pp. 1612-1623. http://dx.doi.org/10.1016/j.phytochem.2011.02.018. PMid:21439598.

HILL, D.S., 1983. Agricultural insect pests of the tropics and their control. Cambridge: Cambridge University Press.

JOSHIPURA, K.J., HU, F.B., MANSON, J.A.E., STAMPFER, M.J., RIMM, E.B., SPEIZER, F.E., COLDITZ, G., ASCHERIO, A., ROSNER, B., SPIEGELMAN, D. and WILLETT, W.C., 2001. The effect of fruit and vegetable intake on risk for coronary heart disease. Annals of Internal Medicine, vol. 134, no. 12, pp. 1106-1114. http://dx.doi.org/10.7326/0003-4819-134-12200106190-00010. PMid:11412050.

KAUL, V., TIKU, A.K., SHANKAR, U. and MONOBRULLAH, M., 2007. Green stink bug (Hemiptera: Pentatomidae) recorded as a new pest of olive in India. Journal of Asia-Pacific Entomology, vol. 10, no. 1, pp. 81-83. http://dx.doi.org/10.1016/S12268615(08)60335-0.

KLIMCZAK, I., MALECKA, M., SZLACHTA, M. and GLISZCZYNSKA-SWIGLO, A., 2007. Effect of storage on the content of polyphenols, vitamin $\mathrm{C}$ and the antioxidant activity of orange juices. Journal of Food Composition and Analysis, vol. 20, no. 3-4, pp. 313-322. http://dx.doi.org/10.1016/j.jfca.2006.02.012.

LEELASUPHAKUL, W., HEMMANEE, P. and CHUENCHITT, S., 2008. Growth inhibitory properties of Bacillus subtilis strains and their metabolites against the green mold pathogen (Penicillium digitatum Sacc.) of citrus fruit. Postharvest Biology and Technology, vol. 48, no. 1, pp. 113-121. http://dx.doi. org/10.1016/j.postharvbio.2007.09.024.

LIN, J.T., ZENG, L., LU, Y.Y., LIANG, G.W. and XU, Y.J., 2004. Research advances in biology and control of Bactrocera (Bactrocera) dorsalis (Hendel). Journal of Zhongkai Agrotechology College, vol. 17, pp. 60-67.

LOUIS, C., GIRARD, M., KUHL, G. and LOPEZ-FERBER, M., 1996. Persistence of Botrytis cinerea in its vector Drosophila melanogaster. Phytopathology, vol. 86, no. 9, pp. 934-939. http:// dx.doi.org/10.1094/Phyto-86-934.

MEDJKOUH, L., TAMENDJARI, A., ALVES, R.C., ARAUJO, M. and OLIVEIRA, M., 2016. Effect of Bactrocera oleae on phenolic compounds and antioxidant and antibacterial activities of two Algerian olive cultivars. Food \& Function, vol. 7, no. 10, pp. 4372-4378. http://dx.doi.org/10.1039/C6FO01136E. PMid:27713969.

MIKANI, A., REZA ETEBA, H. and AMINIAN, H., 2011. Changes in peroxidase and phenols activity in apple fruit inoculated with antagonistic Pseudomonas fluorescens Isolates and Botrytis mali. Pakistan Journal of Biological Sciences, vol. 14, no. 18, pp. 854-861. http://dx.doi.org/10.3923/pjbs.2011.854.861. PMid:22518925. 
MILLER, N.J. and RICE-EVANS, C.A., 1997. The relative contributions of ascorbic acid and phenolic antioxidants to the total antioxidant activity of orange and apple fruit juices and blackcurrant drink. Food Chemistry, vol. 60, no. 3, pp. 331-337. http://dx.doi.org/10.1016/S0308-8146(96)00339-1.

MO, Y., ZHANG, Y. and CHEN, L.Y., 2018. Factors affecting vitamin C content in citrus fruits. Modern Horticulture, vol. 40, no. 2, pp. 1-5.

MRAICHA, F., KSANTINI, M., ZOUCH, O., AYADI, M., SAYADI, S. and BOUAZIZ, M., 2010. Effect of olive fruit fly infestation on the quality of olive oil from Chemlali cultivar during ripening. Food and Chemical Toxicology, vol. 48, no. 11, pp. 3235-3241. http://dx.doi.org/10.1016/j.fct.2010.08.031. PMid:20804813.

NAIDU, K.A., 2003. Vitamin C in human health and disease is still a mystery: an overview. Nutrition Journal, vol. 21, no. 2, pp. 1-7. http://dx.doi.org/10.1186/1475-2891-2-7. PMid:14498993.

NEWELL, I.M. and HARAMOTO, F.H., 1968. Biotic factors influencing populations of Dacus dorsalis in Hawaii. Proceedings of the Hawaiian Entomological Society, vol. 20, no. 1, pp. 81-139.

OMOLOYE, A.A., OLADAPO, O.G., IBITOYE, O. and ALABI, O.Y., 2016. Effects of field attack by Ceratitis capitata Wiedemann (Diptera: Tephritidae) on the morphology and nutritional quality fresh fruit of Citrus sinensis L. African Journal of Agricultural Research, vol. 11, no. 11, pp. 967-973. http://dx.doi.org/10.5897/ AJAR2014.9232.

PADAYATTY, S.J., KATZ, A., WANG, Y., ECK, P., KWON, O., LEE, J.-H., CHEN, S., CORPE, C., DUTTA, A., DUTTA, S.K. and LEVINE, M., 2003. Vitamin C as an antioxidant: evaluation of its role in disease prevention. Journal of the American College of Nutrition, vol. 22, no. 1, pp. 18-35. http://dx.doi.org/10.1080 /07315724.2003.10719272. PMid:12569111.

PANDEY, K.B. and RIZVI, S.I., 2009. Plant polyphenols as dietary antioxidants in human health and disease. Oxidative Medicine and Cellular Longevity, vol. 2, no. 5, pp. 270-278. http://dx.doi. org/10.4161/oxim.2.5.9498. PMid:20716914.

PLAZA, L., ALTISENT, R., ALEGRE, I., VIÑAS, I. and ABADIAS, M., 2016. Changes in the quality and antioxidant properties of fresh-cut melon treated with the bio preservative culture pseudomonas graminis CPA-7 during refrigerated storage. Postharvest Biology and Technology, vol. 111, pp. 25-30. http:// dx.doi.org/10.1016/j.postharvbio.2015.07.023.
RATTANAPUN, W., AMORNSAK, W. and CLARKE, A.R., 2009. Bactrocera dorsalis preference for and performance on two mango varieties at three stages of ripeness. Entomologia Experimentalis et Applicata, vol. 131, no. 3, pp. 243-253. http:// dx.doi.org/10.1111/j.1570-7458.2009.00850.x.

RUIZ-CRUZ, S., CHAPARRO-HERNÁNDEZ, S., HERNÁNDEZRUIZ, K.L., CIRA-CHÁVEZ, L.A., ESTRADA-ALVARADO, M.I., ORTEGA, L.E.G., JESÚS ORNELAS-PAZ, J. and MATA, M.A.L., 2017. Flavonoids: important bio compounds in food. In: J. JUSTINO, ed. Flavonoids: from biosynthesis to human health. Rijeka: Intech Open.

SILALAHI, J., 2002. Anticancer and health protective properties of citrus fruit components. Asia Pacific Journal of Clinical Nutrition, vol. 11, no. 1, pp. 79-84. http://dx.doi.org/10.1046/j.14406047.2002.00271.x. PMid:11890643.

WALSH, D.B., BOLDA, M.P., GOODHUE, R.E., DREVES, A.J., LEE, J., BRUCK, D.J., WALTON, V.M., O'NEAL, S.D. and ZALOM, F.G., 2011. Drosophila suzukii (Diptera: Drosophilidae): invasive pest of ripening soft fruit expanding its geographic range and damage potential. Journal of Integrated Pest Management, vol. 2, no. 1, pp. G1-G7. http://dx.doi.org/10.1603/IPM10010.

WANG, J., WU, C.X. and YAO, J., 2006. Changes of vitamin C content in orange juice stored under different short-term conditions. In: Proceedings of the 2nd Annual Academic Meeting of Shanghai Preventive Medicine Association, 2006, Shanghai. Shanghai: Shanghai Preventive Medicine Association.

WHITEHEAD, S.R. and BOWERS, M.D., 2013. Evidence for the adaptive significance of secondary compounds in vertebratedispersed fruits. American Naturalist, vol. 182, no. 5, pp. 563-577. http://dx.doi.org/10.1086/673258. PMid:24107365.

WHITEHEAD, S.R. and BOWERS, M.D., 2014. Chemical ecology of fruit defence: synergistic and antagonistic interactions among amides from piper. Functional Ecology, vol. 28, no. 5, pp. 1094-1106. http://dx.doi.org/10.1111/1365-2435.12250.

XU, L.L., ZHOU, C.M., XIAO, Y., ZHANG, P.F., TANG, Y. and XU, Y.J., 2012. Insect oviposition plasticity in response to host availability: the case of the tephritid fruit fly Bactrocera dorsalis. Ecological Entomology, vol. 37, no. 6, pp. 446-452. http://dx.doi.org/10.1111/j.1365-2311.2012.01383.x.

ZHANG, B., LIU, Y.H., ZHAO, L.L. and ZHOU, X., 2008. Research progress of oriental fruit fly Bactrocera dorsalis (Hendel). Zhongguo Nongxue Tongbao, vol. 24, pp. 391-396. 